\title{
QUALITY PROFILE OF THE SEMI-DRY EGYPTIAN SALTED MEAT (BASTERMA) AVAILABLE IN MARKETS OF ASSIUT CITY
}

\author{
SH.M.S. ABD-ALLAH and H.A.A. ISMAIL
}

Department of Food Hygiene (Meat Hygiene), Faculty of Veterinary Medicine, Assiut University, Assiut, Egypt Corresponding author: sherief74@yahoo.com

Phone: 0020882411640

Fax: 0020882366503

\begin{tabular}{|c|c|}
\hline & ABSTRACT \\
\hline Received at: $28 / 9 / 2012$ & $\begin{array}{l}\text { A total of } 50 \text { samples of semi-dry Egyptian salted meat (basterma) were randomly } \\
\text { collected from different retail outlets in Assiut city, Egypt. The samples were } \\
\text { examined sensorially for color, odor, taste, tenderness, juiciness, palatability and } \\
\text { overall acceptability; chemically for } \mathrm{pH} \text { and sodium chloride }(\mathrm{NaCl}) \text { content; and } \\
\text { microbiologically for the count of total aerobes, halophiles, Staphylococcus aureus, } \\
\text { lactobacilli, and mould and yeast. As well, most probable number (MPN) count was } \\
\text { performed for coliforms, fecal coliforms, E. coli and Clostridium perfringens. The } \\
\text { obtained results revealed that examined samples were of medium quality from the } \\
\text { sensory point of view. The mean values of pH and Nacl content for the examined } \\
\text { samples were } 4.78 \text { and } 7.30 \text {, respectively. For total aerobes, halophiles, Staph. } \\
\text { aureus, lactobacilli, and mould and yeast counts the mean values were } 7.81,7.18 \text {, } \\
6.62,7.61 \text { and } 2.32 \text { log cfu/g sample, respectively. The MPN count of coliforms } \\
\text { varied greatly in positive samples from } 3 \text { to }>1100 \mathrm{MPN} / \mathrm{g} \text { sample. The MPN count } \\
\text { for fecal coliforms, E. coli and C. perfringenes in positive samples ranged from } 3 \text { to } \\
120 ; 3 \text { to } 21 \text {; and from } 3.6 \text { to } 93 \text { MPN/g, respectively. According to the Egyptian } \\
\text { standards, most of the examined samples ( } 98 \% \text { ) had pH values complied with the } \\
\text { standards limits. However, all the examined samples (100\%) had total aerobic and } \\
\text { Staph. aureus counts above the standards limits. As for total mould and yeast, and } C \text {. } \\
\text { perfringens counts, } 38 \text { and } 24 \% \text { of the examined samples were not complied with } \\
\text { the standards. The results declared that the hygienic quality of basterma available in } \\
\text { Assiut retail markets is not satisfactory and not comply with the srandards. }\end{array}$ \\
\hline
\end{tabular}

Key words: Semi-dry Egyptian salted meat, Basterma, Assessment, Sensory, Chemical, Microbiological.

\section{INTRODUCTION}

Meat and meat products are important for human diet because they provide a great part of nutrients (Simonsen et al., 1988). The determination of the sanitary condition and the prevalence of different food-borne pathogens in foods will indicate the potential health risks to consumers (CDC, 1983).

The microbiological quality and safety of commercially processed meat and poultry products are major areas of concern for producers, consumers and public health officials worldwide (Okolocha and Ellerbroek, 2005). Products excessively contaminated with microorganisms are undesirable from the standpoint of public health, storage, quality and general aesthetics (Cunningham, 1982; Mead, 1989). The quality of meat product depends on the quality of the used meat, additives, sanitary condition of the equipments and the processing procedures (Chesnut et al., 1977; Teufel et al., 1982).

Meat cured with sodium chloride and drying is an ancient preservation method that ensures availability of product today in many countries (Wilson et al., 1981). Contamination of cured meat products with pathogens may occur through improper handling, processing and storage. The factory utensils, workers and the surrounding atmosphere are considered the most important sources of contamination with pathogens (Bryan et al., 1968). The study of the microbial quality of preserved cured meat products is important from the public health point of view. Most of these food products are ready-to-eat without any need for further cooking (Bryan et al., 1968). To ensure the safety of these foods, periodic surveillance to determine the microbiological quality (spoilage and pathogenic agents) is necessary. 
Basterma "Pastirma", a traditional Turkish meat product, is a popular cured and dried meat product in many Islamic countries including Egypt. It is recognized as an intermediate moisture food; its name comes from bastirma, meaning being pressed for the beef is squeezed between stones to lose its water content (Leistner, 1988; Demirezen and Uruc, 2006). Basterma was produced from whole muscle obtained from certain parts of cattle, buffalo and camel carcasses. It requires simple equipment and little energy for preparation. Three steps are involved in the manufacture of Egyptian basterma: curing, drying and covering. Muscles are cleaned of tendon and fat and then cured (common salt and potassium nitrate), dried (at room temperature), pressed (about one ton of pressure applied for $12 \mathrm{hrs}$ ) and coated with paste of $35 \%$ garlic, $20 \%$ fenugreek (Trignnellu foenum gruecum), 5-6\% red paprika and cumin and 38-40\% water; and again dried. The production process of basterma takes approximately a month (El-Khateib et al. 1987; Demirezen and Uruc, 2006). Nowadays, basterma is prepared from the imported boneless frozen beef. Despite of its high nutritive value, basterma may constitute public health hazards due to high salt content, residues of nitrite, presence of nitrosamines, spoilage and pathogenic microorganisms, which may affect the quality of the product leading to economic losses and public health hazards (El-Banna, 1974).

So, the aim of the present study is to through the light on the hygienic (sensory, chemical and microbiological) quality of basterma sold in the retail markets in Assiut city, Assiut province, Egypt and declares how much it complies with the standards.

\section{MATERIALS and METHODS}

\section{Sample collection:}

A total of 50 semi-dry Egyptian salted meat (basterma) samples were randomly collected from different, supermarkets and mini-markets in Assiut city, Assiut province, Egypt. The samples were directly dispatched to the laboratory and subjected to the required investigations (sensory, chemical and microbiological examination) with a minimum of delay. The basterma samples were in slice form and were kept at $4^{\circ} \mathrm{C}$ till all tests were performed.

\section{Sample preparation:}

Using sterile instruments, the outer-coating of the samples was removed. Each sample was divided into two parts, one part used for sensory assessment and the other part was cut into small pieces and thoroughly mixed in sterile mortar as it prepared for microbiological and chemical examination.

\section{Sensory evaluation:}

The sensory parameters were evaluated by members of the department of food hygiene (meat hygiene) faculty of veterinary medicine, Assiut University,
Assiut, Egypt. Three consumer-based sensory panel was conducted to evaluate the color, odor, taste, tenderness, juiciness, palatability and overall acceptability of the basterma samples using a 9-point hedonic scale (Meilgaard et al., 2007), where $9=$ like extremely; ......5 = neither like, nor dislike; and ........1 $1=$ dislike extremely.

\section{Chemical examination:}

Ten grams of each sample was used to determine the $\mathrm{pH}$ value using EC-pH Scan 2 (EUTECH INSTRUMENTS 59000-20) at room temperature according to Lyhs et al. (1998). The salt content of the samples was determined according to the method described by AOAC (1995).

\section{Microbiological assessment:}

In sterile plastic bag 10 grams of the prepared sample were stomached with $90 \mathrm{ml}$ sterile $0.1 \%$ peptone water for 2 minutes using laboratory blender stomacher (Seward 400). Ten folds serial dilutions (up to $10^{6}$ ) were prepared and the appropriate dilutions were surface plated for all counts expect for mould and yeast, they were pour plated. Microbiological analyses were carried out to determine: total microbial flora on plate count agar (Oxoid), total halophilic flora on plate count agar supplemented with $7 \%$ (w/v) $\mathrm{NaCl}$, Staphylococcus aureus count on mannitol salt agar" (Himedia), mould and yeast count on acidified malt extract agar (Oxoid, 1982). All were carried out according to APHA (1984). Lactobacilli were determined on deMan, Rogosa and Sharpe "MRS" (Biolife) agar (deMan et al., 1960). All media were incubated aerobically at $35 \pm 1^{\circ} \mathrm{C}$ for 48 hours, except for lactobacilli, it was incubated in $\mathrm{CO}_{2}(5 \%)$ incubator at $37^{\circ} \mathrm{C}$ for 72 hours; and for mould and yeast, it was incubated at $25^{\circ} \mathrm{C}$ for up to 7 days. Coliforms, fecal coliforms and E. coli most probable number "MPN" counts were done following the procedures described in AOAC (1995). For Clostridium perfringens MPN count; lactose sulphite broth (Biolife) was used and it was incubated at $46 \pm$ $0.5^{\circ} \mathrm{C}$ for 48 hours (Beerens et al., 1982).

\section{RESULTS}

The data presented in Table 1, declared that the examined basterma samples were generally of medium quality from the sensory point of view. The color of the samples varied between light to dark red $(48 \%)$, red brown $(38 \%)$ and greenish red $(14 \%)$. The odors were spicy (58\%), weak (24), sour (10\%), sweet $(4 \%)$, or moldy $(4 \%)$. Samples taste was very salty $(8 \%)$, slight salty to salty $(74 \%)$, plain $(10 \%)$, or bitter $(8 \%)$. As for tenderness, the Samples were either tender $(10 \%)$, slight to moderate tender $(68 \%)$, or slight to moderate tough (22\%). Concerning juiciness, $28 \%$ of samples were juicy, $44 \%$ were slight to medium juicy and $28 \%$ were slight dry. Regarding palatability, $22 \%$ of the samples were palatable, $60 \%$ were slight to moderate palatable and $18 \%$ were not 
palatable. The overall acceptability of the samples varied between like very much $(8 \%)$, moderately like (28\%), slight like $(26 \%)$, neither like nor dislike $(6 \%)$, slight dislike (18\%), and moderate dislike (14\%) (data not shown).

The $\mathrm{pH}$ values of the examined samples ranged from 3.30 to 6.10 with a mean value of 4.78 , while $\mathrm{NaCl}$ contents varied from 4.36 to $12.34 \%$ with a mean value of $7.30 \%$ (Table 2). Out of the 50 examined samples $49(98 \%)$ had $\mathrm{pH}$ values in complies with the Egyptian standards specifications (E.S.S., 2005) for basterma "pH 6" (Table 5). Only 1 sample was above the standards and had $\mathrm{pH}$ value of 6.1.

The minimum, maximum, and mean values for total aerobes, halophiles, Staph. aureus, lactobacilli, and mould and yeast counts in the positive examined samples were declared in Table 3. All the examined samples were positive for total aerobes, halophiles, Staph. aureus and lactobacilli counts. Only 35 (70\%) out of the 50 examined samples showed mould and yeast counts $\geq 1 \log \mathrm{cfu} / \mathrm{g}$ (Table 3 ). The Egyptian standards (E.S.S., 2005) for total aerobes, Staph. aureus, and mould and yeast counts in basterma are 4, zero, and $2 \mathrm{log} \mathrm{cfu} / \mathrm{g}$, respectively. All the examined $(100 \%)$ samples showed a count above the standards limits for total aerobes and Staph. aureus. Out of the 50 examined samples 19 (38\%) had yeast and mould counts above the Egyptian standards limits (Table 5).

As recorded in Table 4, out of the 50 examined samples 34 (68\%), $9(18 \%), 4(8 \%)$, and $12(24 \%)$ were positive for coliforms, fecal coliforms, E.coli and $C$. perfringens MPN counts, respectively. The MPN counts for the previously mentioned microorganisms in the positive examined samples were ranged from 3 to $>1100,3$ to 120,3 to 21 , and from 3.6 to $93 \mathrm{MPN} / \mathrm{g}$; with a median values of 15 , 20, 3.6 and 3.6 MPN/g sample, respectively. It was found that $24 \%$ of the examined samples had C. perfringens counts above the Egyptian standards "sample should be free" (Table 5).

Table 1: Sensory assessment of the examined basterma samples (Mean and SE)

\begin{tabular}{|c|c|c|c|c|c|c|c|c|}
\hline \multicolumn{2}{|c|}{ Character } & \multirow{2}{*}{$\frac{\text { Color }}{5.51}$} & \multirow{2}{*}{$\frac{\text { Odor }}{5.66}$} & \multirow{2}{*}{$\frac{\text { Taste }}{6.21}$} & \multirow{2}{*}{$\begin{array}{c}\text { Tenderness } \\
6.00\end{array}$} & \multirow{2}{*}{$\begin{array}{c}\text { Juiciness } \\
5.66\end{array}$} & \multirow{2}{*}{$\frac{\text { Palatability }}{6.12}$} & \multirow{2}{*}{$\begin{array}{c}\begin{array}{c}\text { Overall } \\
\text { acceptability }\end{array} \\
5.75\end{array}$} \\
\hline \multirow{2}{*}{ Score } & mean & & & & & & & \\
\hline & S.E. & 0.14 & 0.16 & 0.14 & 0.18 & 0.15 & 0.15 & 0.16 \\
\hline
\end{tabular}

Table 2: Statistical values of $\mathrm{pH}$ and $\mathrm{NaCl}$ content of the examined basterma samples $(\mathrm{n} *=50)$

\begin{tabular}{|c|c|c|c|c|}
\hline Item & Minimum & Maximum & Mean & S.E. \\
\hline $\mathrm{pH}$ & 3.30 & 6.10 & 4.78 & 0.10 \\
\hline $\mathrm{NaCl}$ & 4.36 & 12.34 & 7.30 & 0.26 \\
\hline
\end{tabular}

$*_{\mathrm{n}}=$ number of samples

Table 3: Statistical values of total aerobes, halophiles, Staph. aureus, lactobacilli, and yeast and moulds counts $(\log \mathrm{cfu} / \mathrm{g})$ of the examined basterma samples $(\mathrm{n} *=50)$

\begin{tabular}{lccccccc}
\hline \multirow{2}{*}{ Microorganism } & \multicolumn{2}{c}{ Positive samples } & \multirow{2}{*}{ Minimum } & Maximum & Mean & SE \\
\cline { 2 - 6 } Total aerobes & No. & $\%$ & & & & & \\
\hline Halophiles & 50 & 100 & 5.52 & 8.85 & 7.81 & 0.10 \\
\hline Staphylococcus aureus & $49 * *$ & 100 & 3.00 & 8.57 & 6.62 & 0.19 \\
\hline Lactobacilli & $49 * *$ & 100 & 5.53 & 8.90 & 7.61 & 0.10 \\
\hline Total mould and Yeast & 35 & 70 & 1 & 5.72 & 2.32 & 0.22 \\
\hline
\end{tabular}

$* \mathrm{n}=$ number of samples

** one sample was not counted 
Table 4: Statistical values of coliforms, fecal coliforms, E. coli and Clostridium perfringens (MPN/g) of the examined basterma samples $\left(n^{*}=50\right)$

\begin{tabular}{lccccc}
\hline \multirow{2}{*}{ Microorganism } & \multicolumn{2}{c}{ Positive samples } & Minimum & Maximum & Median \\
\cline { 2 - 4 } Coliforms & No. & $\%$ & & $>1100$ & 15.0 \\
\hline Fecal Coliforms & 94 & 68 & 3.00 & 120.00 & 20.0 \\
\hline E.coli & 4 & 8 & 3.00 & 21.00 & 3.6 \\
\hline $\begin{array}{l}\text { Clostridium } \\
\text { perfringens }\end{array}$ & 12 & 24 & 3.60 & 93.00 & 3.6 \\
\hline
\end{tabular}

$* \mathrm{n}=$ number of samples

Table 5: Egyptian standards limits for basterma (E.S.S., 2005).

\begin{tabular}{|c|c|c|c|c|c|c|}
\hline \multirow[t]{2}{*}{ Item } & \multirow[t]{2}{*}{ The standard limit } & \multicolumn{2}{|c|}{$\begin{array}{l}\text { Samples within the } \\
\text { standard limit }\end{array}$} & \multicolumn{2}{|c|}{$\begin{array}{l}\text { Samples above the } \\
\text { standard limit }\end{array}$} & \multirow[t]{2}{*}{$\begin{array}{c}\text { Total } \\
\text { number }\end{array}$} \\
\hline & & No. & $\%$ & No. & $\%$ & \\
\hline $\mathrm{pH}$ & 6 & 49 & 98 & 1 & 2 & 50 \\
\hline Total aerobes & $10^{4}$ & 0 & 0 & 50 & 100 & 50 \\
\hline $\begin{array}{l}\text { Staphylococcus } \\
\text { aureus }\end{array}$ & free & 0 & 0 & 49 & 100 & 49 \\
\hline Mould and yeast & $10^{2}$ & 31 & 62 & 19 & 38 & 50 \\
\hline $\begin{array}{l}\text { Clostridium } \\
\text { perfringens }\end{array}$ & free & 38 & 76 & 12 & 24 & 50 \\
\hline
\end{tabular}

\section{DISCUSSION}

Meat is a good source of animal protein and minerals especially iron (Hammed, 2001). Shelf-stable meat products, such as the dry-cured salt-coated beef produced in Egypt (basterma), are technically considered to be ready-to-eat meat products (ElKhateib, 1997). The curing of meat inhibits the growth of microorganisms and improves the sensory characteristics of final products (El-Sayed, 2006).

Organoleptic and sensory properties of a particular product (primary quality) are the first contact between the consumer and that particular product (Abd ElGafar, 1999). Sensory assessment of the examined basterma samples in the present study revealed that most $(54 \%)$ of them had general acceptability of slight to medium. Only $8 \%$ of the samples were very acceptable, while $6 \%$ were border line. The remaining samples $(32 \%)$ were unacceptable from the sensory point of view. They may have bitter taste, undesirable odor and/or color (data not shown). The obtained results seem to be in partial agreement with those of Saad (1976), Hassan (1997) and Abd El-Gafar (1999). Saad (1976) found that $56.67 \%$ of examined basterma samples had dark red color for meat, while $20 \%$ were purplish red, $13.33 \%$ were dark brown and $10 \%$ were grayish brown. He reported that most of the samples smell spicy or after garlic while putrid, moldy and rancid odors were found in 16.67, 6.67 and $3.33 \%$ of the samples, respectively. He also mentioned that taste were normal specific taste in $73.33 \%$, while unpleasant and rancid taste was in 16.67 and $10 \%$ of the samples, respectively. He found that the consistency was firm in $63.33 \%$ of samples, while the tender and soft consistency was present in 20 and $15.67 \%$ of samples, respectively. On the same trend, Hassan (1997) reported that, 50\% of the examined whole basterma block samples showed normal meat surface cure color, while $26.7 \%$ showed fading color. He observed over cure color (dark red) in $23.3 \%$ of the examined samples and found that the meat surface was firm in $66.7 \%$ of the samples, while $33.3 \%$ had soft texture which may be due to either under pressing or microbial spoilage. He detected normal cure odor of meat, sour, and putrid odor in $80,16.7$ and $3.3 \%$ of the examined samples, respectively. Furthermore, he mentioned that $26.7 \%$ of the slices of cured meat showed a normal cured pink coloration, while $66.7 \%$ showed an over cured cut section indicating high nitrite residue. Abd El-Gafar (1999) mentioned that, of examined basterma samples $55 \%$ were had normal 
cure color while fading and over cure were detected in 10 and $35 \%$ of the samples, respectively. He reported that $60 \%$ of the examined samples were found to be firm, while $40 \%$ had soft texture; which may be due to under pressing or microbial spoilage. He detected normal cure odor of meat in $70 \%$ of the samples, while the rest of samples suffered from sour odor. As well, he detected normal cured pink color in $55 \%$ of the slices of cured meat, while over cure color and fading were detected in 35 and $10 \%$ of the examined samples, respectively.

The $\mathrm{pH}$ of some Foods changes as a result of microbial activity; consequently, $\mathrm{pH}$ determinations have been applied to determine the degree of quality deterioration. However, changes in $\mathrm{pH}$ because of microbial activity vary with conditions such as nature of the food, the type of microbial flora, and packaging conditions "gaseous atmosphere" (National Academy of Sciences, 1985). In the current study, most of the examined samples $(98 \%)$ had $\mathrm{pH}$ values comply with the standards of Egypt for basterma. The obtained values of $\mathrm{pH}(3.30-6.10)$ seem to be lower than those detected by Saad (1976), El Khateib et al. (1987) and Aiedia (1995). As well, the mean pH value in the present study $(4.78 \pm 0.10)$ was lower than those detected by El Khateib (1997) in 50 examined basterma samples $(5.70 \pm 0.19)$, and by Abd El-Gafar (1999) in 20 examined basterma samples (5.32 \pm 0.070$)$.

Salt is introduced into food in processing at two levels either for flavoring at about 2 percent, or for long term preservation at about $18-20$ percent (Ranken, 1986). The obtained $\mathrm{NaCl}$ content mean value $(7.30 \pm 0.26)$ in the current study seems to be nearly similar to those detected by Mousa et al. (1993b), Aiedia (1995) and Abd El-Gafar (1999). However, ElKhateib et al. (1987) recorded a lower mean value for $\mathrm{NaCl}(6.5 \%)$. Higher values were reported by Saad (1976), Mahmoud (1987), El-Khateib (1997) and Hassan (1997), which are 10.52 $\pm 0.34,17 \%$, $8.30 \pm 1.75$, and $8.1 \%$, respectively.

It is well known that the microflora of any foodstuff is qualitatively and quantitatively affected by so many factors. Important among them are the physical and chemical properties of food, its ingredients, presence of inhibitors or stimulators, the microbial load of raw materials, sanitary conditions of production, the extent of the thermal treatment, ...etc (Tawfeek et al., 1989). The study of the microbial quality of preserved cured meat products is important from the public health point of view. Most of these food products are readyto-eat without any need for further cooking. Thus contamination of these products with pathogens is considered a serious problem (Bryan et al., 1968).

The aerobic plate count may have no overt public health significance, but it may indicate that the finished product has been mishandled. Further more it may be indicative of neglected sanitary measures in curing, processing, handling, as well as the use of low quality ingredients (Yassien, 1988). In the present study the total aerobes count was high and it exceeded the recommended standards of Egypt in all the examined samples which is in harmony with that recorded by Abd-El-Shahid and Ibrahim (2010). Nearly similar counts to the current finding were recorded by Saad (1976), Abd El-Aziz (1987), ElKhateib et al. (1987) and Abd El-Gafar (1999). On the other hand, Hemeida et al. (1986), Yassien (1988), Mousa et al. (1993a), Tolba (1994), Aiedia (1995), El-Khateib (1997), and Abd-El-Shahid and Ibrahim (2010) examined a variety of basterma samples and recorded total aerobes mean values of $2.3 \times 10^{5}$, $2 \times 10^{5} \pm 8 \times 10^{4}, 4.7 \times 10^{6}, 5.5 \times 10^{2} \pm 10^{2}, 1.7 \times 10^{6}, 1.4 \times 10^{5}$, and $3.0 \times 10^{6} \mathrm{cfu} / \mathrm{g}$ sample, respectively, which are lower than the present finding $(7.81 \pm 0.10)$. Increase in the count of aerobic bacteria in the samples may be attributed to spices that are used for the manufacturing of basterma. Christensen et al. (1967) reported that some spices harbor numerous microorganisms, including spore-forming bacteria and spoilage organisms. Unless spices are chemically or thermally treated or irradiated they may contaminate menu items and cause spoilage and may even introduce harmful organisms (Strong et al. 1963). The high count may also be due to neglected sanitary measures or the use of low quality ingredients. The use of imported frozen beef for basterma manufacturing in Egypt, nowadays, might be related to this high count. The aerobic plate count may have no overt public health significance, but it may contribute to some degree toward spoilage of a product containing spices (Julseth and Deibel, 1974).

Although salt prevents growth of spoilage bacteria, other microorganisms may not be affected by its presence. The microbial types associated with a particular salted food depend on the concentration and type of salt and the type of food. Microorganisms have been conveniently divided into four groups based on their sensitivity to salt: halotolerant, slight halophiles, moderate halophiles and extreme halophiles. Most halotolerant microorganisms are isolated when foods are tested for slight or moderate halophiles. Some halotolerant microganisms are involved in the spoilage of salted foods, whereas others, such as Staph. aureus are human pathogens (APHA, 1984; Baross and Lenovich, 1992). In the present study, the mean, minimum and maximum values of halophilic bacteria count were high which are indicative of neglected sanitary measures or the use of low quality salt in the process. Mahmoud (1987) found a mean halophilic bacterial count in market basterma samples of $8.73 \times 10^{7}$, which is nearly similar to the current finding.

Staphtaphylococcus aureus is a salt-tolerant microorganism that can grow at water activity levels as low as 0.83 to 0.84 , depending on the product. Enterotoxins causing intoxication could be produced 
during growth of Staph. aureus at water activity values of $\geq 0.86$. The release of enterotoxin by Staph. aureus can occur if population exceeds ca $10^{7} \mathrm{cfu} / \mathrm{g}$ (Tatini, 1973, Tatini et al., 1973 and Boylan et al., 1976). In the present study Staph. aureus count was high and $40.82 \%$ of the samples showed count $>10^{7} \mathrm{cfu} / \mathrm{g}$ (data not shown). The count exceeded the recommended standards of Egypt in all the examined samples which are in agreement with the results of Abd-El-Shahid and Ibrahim (2010). Lower percentages were reported by Refai (1984) and Abd El-Gafar (1999) who found that staph. aureus count exceeded the recommended standards of Egypt in 46.7 and $80 \%$ of examined basterma samples, respectively. Lower mean values of Staph. aureus count were detected by Refai (1984), Abd El-Aziz (1987), Mousa et al. (1993a), Hassan (1997), Abd ElGafar (1999), Abd-El-Shahid and Ibrahim (2010) and Saleh et al. (2010). Higher value $\left(1.7 \times 10^{7}\right)$ was detected by Rageh (1980), and nearly similar value $\left(4.4 \times 10^{6}\right)$ was detected by Tolba (1986). The presence of high densities of organisms shows typical characteristics of Staph. aureus in processed cured meat products might pose a potential health hazard and it indicates non-hygienic production control (Tawfeek et al., 1989).

In products with low water activity such as heavily cured meat products, a salt-resistant microflora develops in the initial phase, before the water activity drops below 0.90-0.85; this flora is composed of lactobacilli (Simonsen et al., 1988). Lactic acidproducing bacteria are able to grow under a variety of conditions that prevent the growth of gram-negative aerobes (Egan, 1983). The counts of lactobacilli recorded in the present study were higher than those recorded by El-Khateib (1997) in 50 examined basterma samples. He detected counts ranged from $1 \times 10^{4}$ to $1 \times 10^{7}$ with a geometric mean of $3.9 \times 10^{6}$ $\mathrm{cfu} / \mathrm{g}$. Tawfeek et al. (1989) detected a mean count of $6.9 \times 10^{3}$ for acid producing bacteria in basterma samples collected from Jeddah markets, Jeddah, Saudi Arabia.

Moulds and other osmophilic microorganisms are involved in the spoilage of foods with low water activity values including salted foods (APHA, 1984). For basterma, the effects of processing and the ingredients in the coating layer showed that garlic $(35 \%)$ in the paste protects it from mould for at least 12 days even under unfavorable conditions "i.e., high inoculum of mould, storage at $25^{\circ} \mathrm{C}$ with $90 \%$ relative humidity". When the relative humidity is lower than $90 \%$, the use of $35 \%$ garlic in basterma paste is likely to protect it from mould for several months (ElKhateib et al., 1987). The total mould and yeast count in the current investigation exceeded the Egyptian standards in $38 \%$ of the examined samples. Lower percentage was reported by El-Khateib et al. (1987), while higher ones were found by Abd El-Gafar (1999), and Abd-El-Shahid and Ibrahim (2010). The high incidence of mould and yeast count might be attributed to use of lower garlic percentage $(<35 \%)$ in basterma paste beside to neglected sanitary measures in curing, processing and handling. The current mean value of mould and yeast was lower than those detected by Hemeida et al. (1986), Edris and Salem (1990), Hassan (1997), Abd El-Gafar (1999), and Abd-El-Shahid and Ibrahim (2010) however, it was higher than that recorded by El-Khateib et al. (1987). Nearly similar count was reported by Ouf et al. (2010). Contamination of foods by moulds can result in substantial economic losses to producer, processor, and consumer. Moulds can cause various degrees of deterioration and decomposition of foods. Abnormal flavors and odors may also be produced. Several food-borne moulds may also be hazardous to human health because of their ability to produce toxic metabolites known as mycotoxins (FDA, 1992).

From hygienic point of view, it is of great importance to determine the possibility of fecal contamination of preserved cured meat products. Such study is highly important since most of these products are eaten without any further thermal treatment. Thus the presence of enteric pathogens in these foodstuffs will be a serious problem. The presence of coliforms in cured meat indicates non-sanitary conditions of production (Tawfeek et al., 1989). The present coliforms, fecal coliforms, and E. coli MPN counts were $>3$ in 68,18 , and $8 \%$ of the examined samples, respectively. Higher incidences were detected by Yassa (1985); Abd El-Gafar (1999); and Abd-ElShahid and Ibrahim (2010) for coliforms, which were 82, 70 and $100 \%$, respectively. As well, Abd El-Gafar (1999) reported higher incidence for fecal coliforms (30\%). Escherichia coli were detected at lower rates by Hemeida et al. (1986), Tolba (1986), Tolba (1994), and Abd El-Gafar (1999); and at higher rates by Saad (1976), El-Safey and abdul-Raouf (2003). Nearly similar rates for E. coli were recorded by Zaki (1990), Aiedia (1995) and Saleh et al. (2010). As for coliforms count nearly similar values were detected by Saad (1976), Yassa (1985), Yassien (1988), and Abd-El-Shahid and Ibrahim (2010). Higher counts were recorded by Abd El-Aziz (1987) and Mousa et al. (1993a), while Al-Cherif (1983) and Tolba (1994) recorded lower counts. Concerning fecal coliforms; lower count was were detected by Al-Cherif (1983) and Yassien (1988), while nearly similar count was recorded by Abd El-Gafar (1999). Lower E. coli count $(8 \pm 5.80)$ was recorded by Al-Cherif (1983).

Food illness caused by Clostridium perfringens is among the common illnesses resulting from the consumption of contaminated food, the vehicles of infection are typically meat and poultry products. $C$. perfringens is more widely spread than other pathogenic bacteria; its principal habitats are in the soil and the intestinal contents of man and animals (Hayes, 1992). The microorganism contaminates meat via containers, handlers, water, and dust (Jay, 1992). 
In the present investigation $24 \%$ of the examined samples showed $C$. perfringens count $>3 \mathrm{MPN} / \mathrm{g}$. ElLawendy (1996), Khater (2004), and Atwa and Abou El-Roos (2011) recorded lower incidences of $C$. perfringens in basterma, which were 16, 20 and 16\%, respectively. Higher counts of anaerobic bacteria were detected in basterma by Yassa (1985), Mahmoud (1987), Tawfeek et al. (1989), Aiedia (1995), Hassan (1997) and Abd El-Gafar (1999). Clostridium perfringens has a great effect on the human health causing food poisoning, however millions of viable $C$. perfringens are required to induce the illness $\left(10^{6}\right.$ microorganisms/g food); also it causes a number of human diseases ranging from necrotic enteritis to wound infection and life threatening gas gangrene (Atwa and Abou El-Roos , 2011).

In conclusion, the hygienic quality of Egyptian basterma sold in Assiut city is not satisfactory and should be improved. The high counts of total aerobes, halophiles and Staph. aureus and the presence of coliforms and fecal coliforms indicate that the product be produced under unsanitary hygienic conditions of processing, storage or handling; and/or low quality ingredients may be used for its production. The presence of $C$. perfringens, E. coli and high counts of Staph. aureus indicate that the product might pose potential health hazard to consumers. So, careful inspection of raw materials, production lines and storing conditions should be intensified to eliminate serious contamination of this product with spoilage microorganisms and human pathogens. As well new regulations are required for Egyptian basterma to establish precise and practical microbiological standards limits for coliforms, fecal coliforms, $C$. perfringens, halophiles and Staph. aureus contaminations.

\section{REFERENCES}

Abd El-Aziz, A.T. (1987): Microbial load of some meat products as influenced by the hygienic status of the producing plant. MVSc Thesis (Meat Hygiene). Fac. Vet. Med., Cairo University, Egypt.

Abd El-Gafar, N.S.A (1999): Studies for improving the quality of locally manufactured pastirma. MVSc Thesis (Hygiene and Control of Meat). Fac. Vet. Med., Beni-Suef, Cairo University, Egypt.

Abd-El-Shahid, Y.S.Y. and Ibrahim, H.A.A. (2010): Hygienic significance of microbial counts in some meat products. Alex. J. Vet. Sci., 29 (1): 61-73.

Aiedia, H.A. (1995): Quality investigation into room kept traditional meat products in Egypt. Ph.D. Thesis. Vet. Sci., Fac. Vet. Med., Cairo University, Egypt.
Al-Cherif, A.M. (1983): Sanitary status of meat factory. MVSc. Thesis. Fac. Vet. Med., Cairo University, Egypt.

AOAC (1995): Official Methods of Analysis of AOAC international. $16^{\text {th }}$ Ed., Cunniff, Patricia (Edt.). AOAC international, Virginia, USA: Association of Official Analytical Chemists.

APHA (1984): Compendium of Methods for the Microbiological Examination of Foods. Speck, H. L. (Edt.), APHA, $2^{\text {nd }}$ Ed., Washington D.C.: American Public Health Association.

Atwa, Elham, I. and Abou El-Roos, Nahla, A. (2011): Incidence of Clostridium perfringens in meat products at some Egyptian Governorates. Int. J. Microb. Research, 2 (3): 196-203.

Baross, J.A. and Lenovich, L.M. (1992): Halophilic and osmophilic microorganisms. In: Compendium of Methods for the Microbiological Examination of Foods, $3^{\text {rd }}$ Ed., Vanderzant, C. and Splitsroesser, D.F. (Edts.), p. 199-212. Washington, D C. American Public Health Association.

Beerens, H.; Romond, Ch.; Lepage, C. and Criquelion, J. (1982): A liquid medium for the enumeration of Clostridium perfringens in foods and faeces. Technical series - Society for Applied Bacteriology, (17): 137-149.

Boylan, S.L.; Acott, K.A. and Labuza, T.P. (1976): Staphylococcal aureus challenge study in an intermediate moisture food. J. Food Sci., 41: 918-921.

Bryan, F.L.; Ayres, J.C. and Kraft, A.A. (1968): Salmonellae associated with further processed turkey products. Appl. Microbiol., 16: 1-9.

CDC (1983): Annual summary 1981. Foodborne disease surveillance. Center for Disease Control, Atlanta, Georgia.

Chesnut, C.M.; Emswile,r B.S. and Kotula, A.W. (1977): Bacteriological quality of ingredients used in ground beef manufacture. Journal University of Toronto press, Toronto and Buffalo, Canada.

Christensen, C.M.; Fanse, H.A.; Nelson, G.H.; Bates, F. and Mirocha, C.J. (1967): Microflora of black and red pepper. Appl. Microbiol. 55: 622-626.

Cunningham, F.C. (1982): Microbiological aspects of poultry and poultry products. An update. J. Food Prot., 45: 1149-1164.

deMan, J.C.; Rogosa, M. and Sharp, Elisabeth, M. (1960): A medium for the cultivation of lactobacilli. J. Appl. Bact., 23 (1): 130-135.

Demirezen, D. and Uruc, K. (2006): Comparative study of trace elements in certain fish, meat and meat products. Meat science, 74: 255-260.

E.S.S. "Egyptian Standards Specifications" (2005): Egyptian Organization for Standardization and Quality Control. Egyptian standards, Basterma, E.S :1042 
Edris, A.M. and Salem, M.A. (1990): Microflora of pastirma. Banha Vet. Med. J., 1: 103.

Egan, F.A. (1983): Lactic acid bacteria of meat and meat products. Antonie van Leeuwenhoek, 49: 327-336.

El-Banna, N.H. (1974): Comparative study of the chemical composition and effect of processing on some locally meat products. MSc Thesis, High Institute of Home Economic, Ministry of High Education.

El-Khateib, T. (1997): Microbiological status of Egyptian salted meat (basterma) and fresh sausage. J. Food Safety, 17: 141-150.

El-Khateib, T.; Schmidt, U. and Leistner, L. (1987): Microbial stability of Turkish pastirma. Fleischwirtschaft, 67(1): 101-105.

El-Lawendy, T.M.H. (1996): Occurrence of Clostridium perfringens in locally produced meat products. MVSc Thesis (Food Hygiene and Control). Fac. Vet. Med., Zagazig University, Benha Branch, Moshtohor, Egypt.

El-Safey, E.M. and Abdul-Raouf, U.M. (2003): Detection of Escherichia coli O157:H7 in some Egyptian foods. Assiut J. Agric. Sci., 34(6): 373-379.

El-Sayed, A.E. (2006): Organoleptic and chemical evalution of some locally manufactured beef burger. MVSc Thesis (Meat Hygiene). Fac. Vet. Med., Benha University, Moshtohor, Egypt.

FDA (1992): Bacteriolgical Analytical Manual, $7^{\text {th }}$ Ed. AOAC International, Arlington, USA. Food and Drug Administration.

Hammed, M.I. (2001): Chemical evalution of non meat ingredients in some meat product. $\mathrm{Ph}$. D. Thesis, Faculity of Veterinary Medicine, Cairo Univ., Egypt.

Hassan, O.A. (1997): Impact of component of pastirma on its organoleptic, bacteriological and chemical status. MVSc Thesis (Hygiene and Control of Meat). Fac. Vet. Med. Cairo University, Egypt.

Hayes, P.R. (1992): Food Microbiology and Hygiene. $2^{\text {nd }}$ Ed., Elsevier Applied Science London, New York

Hemeida, H.H.; Hallabo, S.A. and El-Wakeil, F.A.(1986): Chemical and microbiological evaluation of some cured meat products. Bull. Fac. Agric. Cairo Univ., 37 (1): 259-267.

Jay, J.M. (1992): Modern Food Microbiology, $4^{\text {th }}$ Ed., Chapman \& Hall, New York.

Julseth, R.M. and Deibel, R.H. (1974): Microbial profile of selected spices and herbs at import. J. Milk Food Technol. 37: 414-419.

Khater, Dalia, K.F. (2004): Studies on microbial toxin in some vacuum packed meat products. Ph.D. Thesis. Fac. Vet. Med., Zagazig University, Egypt.

Leistner, L. (1988): Shelf-stable products and intermediate moisture foods based on meat. In
Water Activity: Theory and Applications to Food, Rockland, L.B. and Bouchat, L.R. (Edts.) pp. 295-237. New York, Marcel Dekker, Inc.

Lyhs, U.; Hatakka, M.; Maki-Petays, N.; Hyytia, E. and Korkeala, H. (1998): Microbiological quality of Finnish vacuum-packaged fishery products at retail level. Archiv fur Lebensmittelhygiene, 49 (6): 146-150.

Mahmoud, M.H. (1987): Studies on the pastirma. MSc Thesis. Fac. Agric., Zagazig University, Egypt.

Mead, G.C. (1989): Hygenic problems and control of process contamination. In: processing of poultry, Mead, G.C. (Edt.), p: 183-221. London, Elsevier, Applied Science. Libby, T.A., 1975. Meat Hygiene $4^{\text {th }}$ Ed. Lea and Febiger, Philadelphia, U.S.A.

Meilgaard, M.; Civille, G.V. and Carr, B.T. (2007): Sensory Evaluation Techniques, $4^{\text {th }}$ Ed., CRC Press, Boca Raton, FL.

Mousa, M.M.; Awad, H.A.; Yassien, M.M. and Gouda, H.I. (1993a): Microbial quality of some meat products. Vet. Med. J. Giza, 41(3): 59-62.

Mousa, M.M.; Samaha, I.A. and Edris, A.M. (1993b): Chemical composition of some locally manufactured meat products. Alex. J. Vet. Sci., 9(3): 123-125.

National Academy of Sciences (1985): An Evaluation of the Role of Microbiological Criteria for Foods and Food Ingredients. National Academy Press, Washington D.C.

Okolocha, E.C. and Ellerbroek L. (2005): The influence of acid and alkaline treatments on pathogens and the shelf life of poultry meat. Food Control, 16: 217-225.

Ouf, Jehan M.; Khafaga, nagwa I.M. and Shabana, E.S.E. (2010): Incidence of proteolytic and lipolytic moulds and yeasts in some ready to eat meat products. Assiut Vet. Med. J., 56 (126): 132-143.

Oxoid (1982): The Oxoid Manual of Culture Media, Ingredients and Other Laboratory Services. $5^{\text {th }}$ Ed., pp. 186. Oxoid Limited Hampshire, England.

Rageh, E.A. (1980): Staphylococci among some meat products. MVSc Thesis. Fac. Vet. Med., Cairo University, Egypt.

Ranken, M.D. (1986): Food Industries Manual. 21 $1^{\text {st }}$ Ed. Hill, L. (Edit), Glasgow and London.

Refai, R.S. (1984): Enterotoxigenicity of Staph. aureus in meat and meat products. Ph.D. Thesis. Fac. Vet. Med., Cairo University, Egypt.

Saad, M.S. (1976): Studies on the sanitary conditions of locally manufactured pastirma. MVSc Thesis (Meat Hygiene). Fac. Vet. Med., Zagazig University, Egypt. 
Saleh, E.A.; Ali, H.A. and Abu-Khadra, A.M. (2010): Detection of some food poisoning microorganisms in some meat products. Alex. J. Vet. Sci., 31 (1): 27-33.

Simonsen, B.; Hamm, R. and Rogowski, B. (1988): Meat as food. In: Meat Science, Milk Science and Technology, Cross, H.R. and Overby A.J. (Edts.). Chapt. 4, pp. 115-140, Elsevier Science Publisher B.V., Amsterdam.

Strong, D.H.; Canada, J.C. and Griffiths, B.B. (1963): Incidence of Clostridium perfringens in American foods. Appl. Microb. 11: 42-44.

Tatini, S.R. (1973): Influence of food environments on growth of Staphylococcus aureus and production of various enterotoxins. J. Milk Food Technol., 36: 559-567.

Tatini, S.R.; Wesala, W.D.; Jezeski, J.J. and Morris, H.A. (1973): Production of staphylococcal enterotoxins A in blue, brick, mozzarella and Swiss cheeses. J. Dairy Sci., 56: 429-434.

Tawfeek, K.A.; Abdel-Hafez, A.M. and Feda, A.A. (1989): Microbiological quality of cured meat in Jeddah markets. J. King Abdulaziz Univ. Sci. J., 1(1): 39-50.
Teufel, P.; Goetz, G. and Grossklaus, D. (1982): Effect of factory hygiene and raw material on the microbiological status of minced meat. Fleischwirtschaft, 62(11): 1404-1408, 1454.

Tolba, K. (1986): Antibiotic resistant microorganisms in some meat products. MVSc Thesis. Fac. Vet. Med., Cairo University, Egypt.

Tolba, K. (1994): Microflora in locally processed frozen meat. Vet. Med. J. Giza, 42(2): 99-105.

Wilson, N.R.; Dyett, E.J.; Hughes, R.B. and Jones, C.R. (1981): Meat and Meat Products, Factors Affecting Quality Control, Applied Science Publishers, London.

Yassa, A.E. (1985): Studies on bacterial toxin in some food. Ph.D. Thesis. Fac. Agric., Ain-Shams University, Cairo, Egypt.

Yassien, N.A. (1988): Sanitary improvement of locally manufactured meat products. Ph.D. Thesis. Fac. Vet. Med., Cairo Univ. Egypt.

Zaki, S.M.E. (1990): Escherichia coli in meat products with special reference to enterotoxogenic strains. MVSc Thesis. Fac. Vet. Med., Cairo University, Egypt.

\section{صورة جودة اللحوم المصرية شبه الجافة المملحة (العسطرمة) المكاولة في أسواق مدينة أسيوط شريف محمد سيا عبد الله ، هشام عبد الدعز أحعد إسعاعيل}

